\title{
The Promise of Precommitment in Democracy and Human Rights: The Hopeful, Forgotten Failure of the Larreta Doctrine
}

\author{
Tom Long and Max Paul Friedman
}

\begin{abstract}
Although international precommitment regimes offer a tool to escape the apparent contradiction between sovereignty and the international protection of democracy and human rights, they raise theoretical and practical questions. This article draws on multinational archival research to explore an overlooked historical episode and suggest new thinking regarding the logjams over sovereignty, incapacity of global decision making, and humanitarian imperialism. In 1945 and 1946, the American states engaged in a debate over the Larreta Doctrine, a Uruguayan proposal about the parallelism between democracy and human rights, and the regional rights and duties to safeguard these values. In the ensuing debate, the Uruguayan foreign minister elaborated a tripartite precommitment mechanism to create a web of national commitments to democratic governance and the domestic protection of human rights, to establish a regional insurance policy against failures to maintain those commitments, and to obligate the great power and neighboring states to precommit to working through the regional system instead of unilaterally. As a proposal that emerged from a weak state — and garnered support from states that faced internal and external threats to democracy and rights—the Larreta Doctrine offers insights on the central tension between state sovereignty and international commitments.
\end{abstract}

Tom Long (T.Long.1@warwick.ac.uk) (1) is an associate professor in the Department of Politics and International Studies at the University of Warwick, United Kingdom, and an affiliated professor in International Studies at the Centro de Investigación $y$ Docencia Económicas, Mexico City. He is the author of Latin America Confronts the United States: Asymmetry and Influence (Cambridge University Press, 2015). His work has appeared in journals including International Security, International Affairs, International Studies Review, and the Latin American Research Review.

Max Paul Friedman (friedman@american.edu) is a professor of History and International Relations at American University in Washington, DC. He is the author of Rethinking Anti-Americanism: The History of an Exceptional Concept in American Foreign Relations (Cambridge University Press, 2012) and Nazis and Good Neighbors: The United States Campaign against the Germans of Latin America in World War II (Cambridge University Press, 2003). He coedited, with Padraic Kenney, Partisan Histories: The Past in Contemporary Global Politics. He is currently a Friedrich Wilhelm Bessel Fellow of the Humboldt Foundation at the Lateinamerika-Institut of the Freie Universität Berlin.

The authors thank Par Engstrom, Luke Glanville, Eric Hershberg, Stefano Palestini Céspedes, Shirin Rai, Jessica di Salvatore, and Vincenzo Bove for their suggestions; Roberto Garcia Ferreira for his generous sharing of documents; and Paul Behringer for his indispensable research assistance. For financial support and intellectual engagement Max Paul Friedman thanks American University's College of Arts and Sciences, the Humboldt Foundation, the Lateinamerika-Institut at the Freie Universität Berlin, and the US Studies Centre Visiting Scholar Fellowship Program at the University of Sydney. Tom Long thanks the British Academy and Leverhulme Trust, the Truman Library Institute, and the British Council for financial support and the Fundação Getúlio Vargas and Universidad de los Andes for providing congenial working environments in Rio de Janeiro and Bogotá, respectively. 
prosecution of state leaders through the International Criminal Court. Although much of the debate over international protections has emerged from large states, the tension is perhaps most vividly experienced by small and vulnerable states. Weaker states often have deployed the principles of sovereignty and non-intervention, effectively "internalizing and appropriating the international legal discourse" (Lorca 2014, 5) in defense against overbearing powers. However, it is equally clear that those same legal principles are vulnerable to cynical abuses to avoid scrutiny of repressive domestic practices. Although small and vulnerable states may sincerely value democracy and human rights, they hesitate to shed the shield of sovereignty given past and present overreach dressed in humanitarian rhetoric.

Given the international context of power disparities and the presence of domestic liberal traditions dating to independence, the tension between seemingly conflicting goods has a prominent history in the international relations of the Americas (Cooper and Legler 2006; Sikkink 1996). In that context, this article explores a Uruguayan proposal known as the Larreta Doctrine. In late 1945, Uruguayan foreign minister Eduardo Rodríguez Larreta ${ }^{1}$ proposed an inter-American responsibility for the advancement of human rights and democracy, which he saw as ultimately inseparable. Actions to safeguard democracies and human rights would be permitted in advance by a government drawing its legitimacy from the people and therefore would not violate national sovereignty. His conceptualization rested on an idea of popular sovereignty and the notion that states are charged with "internal and external duties." He therefore called on American states to endorse "multilateral collective action" to sustain democracy and the "rights of man and of the citizen." Internationally, the proposal emerged from a perception of "parallelism" between domestic democratic practice and respect for rights, on the one hand, and interAmerican regional peace, on the other. Nondemocracies and violators of human rights were presumed to be a threat to their neighbors.

Under the Larreta Doctrine, all American states would make a tripartite commitment. The first layer created a web of national commitments that treated democratic governance and the domestic protection of human rights as ultimately inseparable. The second established an insurance policy against failures to maintain those commitments. The third aspect—central for Rodríguez Larreta but overlooked by US diplomats when they smiled on the proposal-was a great power precommitment to work through the regional system instead of unilaterally. Crucially, the proposal required the approval of a supermajority of a regional organization before protective action could be undertaken. The Uruguayan recognized that the burden of enforcing any collective commitment would rely disproportionately on the historically interventionist United
States, making its incorporation and its restraint equally crucial. The Larreta Doctrine advocated the early application of nonmilitary means, avoiding some of the problems of coercive democracy promotion. In this sense, it foreshadowed and can enrich calls to increase attention to preventive means of protecting human rights and consolidating democracy without military intervention (Glanville 2017; Poast and Urpelainen 2015).

Scholarly proposals to recast sovereign commitments through precommitment regimes for the defense of democracy and human rights have emerged as one potential avenue to overcome the tension between sovereignty and international commitments (Buchanan and Keohane 2011; Ikenberry and Slaughter 2006). In a similar light, we argue that the Larreta Doctrine can be understood as an early proposal for a precommitment regime to defend democracy and human rights. We build on Buchanan and Keohane's $(2011,55)$ definition of democratic precommitment regimes as "a contract by which a democratic government would authorize intervention in its own territory in response to violence that the government was unable to control, either due to incapacity or to having been dislodged from power by force." For our purposes, international precommitments to democracy and human rights are broader than their definition in two respects. First, a nondemocratic government could forge such an international contract either against rights abuses (R2P would provide such an example) or as a positive commitment to democratize. Second, such a contract does not have to authorize exclusively military, territorial intervention, as conceived by Buchanan and Keohane (e.g., Glanville 2017).

The Larreta Doctrine illustrates another overlooked aspect of precommitment. Precommitments are seen as granting prerogatives to large states to intervene in certain circumstances; the benefits for small states that might suffer intervention have been discussed in terms of defense of a democratic regime from domestic nondemocratic adversaries (Closa and Palestini 2018; Pevehouse 2002). Although that was one concern for the author of the Larreta Doctrine, he also worried about undemocratic subversion or intervention from abroad. Precommitment was a tool both to promote a more democratic, and therefore more secure region, and to restrain interventionist powers, including the United States, that might abuse the rhetoric of democracy and rights to pursue unilateral ends. In short, precommitment can be a tool for small states to pursue security in an asymmetrical context. We define an international precommitment regime as a contract by which a state or group of states recognizes as legitimate future measures by other signatories for the advancement or preservation of democratic practice andlor the defense of human rights, under specified conditions and through specified mechanisms and processes. 
The literature on international precommitments has stressed both the international motivations of great powers and the domestic, regime-level incentives of small states. Although those facets are important, our definition emphasizes the international motivations of small and vulnerable states, particularly concerning possible interventions. This article combines IR theoretical work on international precommitments with the multidisciplinary literature on the Global South's historical engagements with international law (Lorca 2014; Scarfi 2017). This latter body of work emphasizes the defensive attachment to norms of sovereignty and non-intervention. Our case emerges from the post-World War II inter-American system, which seems unlikely terrain for two reasons. First, the Latin American attachment to non-intervention is well documented. Second, despite the work of Sikkink (1996, 2014), post-World War II regional-order building in the Americas is largely understood as the culmination of the US hegemonic project. The inter-American system later became an important zone for the creation of human rights regimes (Lutz and Sikkink 2000; Sikkink 2014) and regional commitments to democracy (Cooper and Legler 2006). Our exploration of the Larreta Doctrine illuminates the efforts of a small Latin American state to reshape norms and practices around democracy, rights, and intervention, debates that shaped the foundations of today's inter-American system.

This episode has received limited historical study, perhaps because the Larreta proposal ultimately failed to overcome Latin American skepticism about diluting the recent, hard-won US commitment to non-intervention-especially given many contemporary governments' dubious democratic credentials. Failed diplomatic effects rarely receive substantial attention, but as Hathaway and Shapiro (2017) have recently argued regarding the Kellogg-Briand Pact, and several authors have noted regarding the Bandung Conference, failed initiatives can reshape norms and affect later institutional trajectories. Although the Larreta Doctrine was not as far-reaching as those hopeful failures, ${ }^{2}$ it left footprints regarding the reconceptualization of (non)intervention that shaped inter-American institutions during the post-World War II critical juncture. The Larreta Doctrine achieved substantial support and created institutional space and a textual legacy for later institutional deepening of protections for human rights and democracy in the Americas. A closer reading of the period, including the Larreta Doctrine, shows crucial Latin American contributions on issues of security, democracy, rights, and international organization often overlooked in US-centric studies of the period.

Although the Inter-American Democratic Charter and other similar, more recent forms of international precommitment have been fairly successful in addressing classic military coups, they have been weak when confronting incumbent leaders over rights abuses and dem- ocratic decline (Feldmann, Merke, and Stuenkel 2019; Heine and Weiffen 2015). The Larreta Doctrine suggests a different set of tools for addressing the tension between non-intervention and international precommitments in those problematic cases-indeed, the type of situations that spurred the Uruguayan proposal. The Larreta Doctrine's failure offers empirical, conceptual, and practical material from outside the European context and that predates post-Cold War regional efforts to enshrine democracy and human rights. That the proposal originated with a small state that feared intervention, and that it gained the support of other small Latin American states, suggests that the commitments and interests of both great and small powers require equal attention if precommitment regimes are to be made viable and perceived as legitimate.

The article proceeds as follows. First, we situate our discussion of the Larreta Doctrine in the literature on the sovereignty and the legitimacy of international human rights and democracy protection, particularly regarding proposals for international precommitments as a solution to this dilemma. Then we turn to the inter-American and Latin American contexts, in which the Larreta Doctrine is best understood and on which it exercised, we argue, lasting effects. In the empirical core of the article, we examine how the proposal of the Larreta Doctrine unfolded, drawing on original archival research in Brazil, Chile, Colombia, Mexico, the United States, and Uruguay. We explore the responses of key states, the proposal's failure, and its legacy. We conclude by assessing the implications for today's still thorny debates about how precommitments relate to sovereignty, popular will, and the collective promotion of individual well-being.

\section{Sovereignty, Intervention, and Precommitment}

As Krasner (1999) noted, norms of sovereignty have always been enunciated in juxtaposition with claims for the legitimacy of certain types of intervention. The concept of state sovereignty that IR traditionally ascribed to the 1648 Peace of Westphalia was refined over time by legal philosophers such as Vattel and Wolff, who articulated the corollary principle of non-intervention. If the eighteenth century saw efforts to enshrine nonintervention into international law, the nineteenth century featured philosophical and legal challenges to it. Formulas for intervention against the sovereign consent of the target state often have problematic roots in Eurocentric assertions of moral superiority and a civilizing mission. Whyte $(2016,314)$ argues that, under the conventional Westphalian narrative, "non-intervention applied only to European states or those deemed civilized, while most of the world was open to European colonialism." John Stuart Mill wrote that "the whole doctrine of noninterference with foreign nations should be reconsidered." Non- 
intervention was appropriate "between one civilized nation and another," Mill argued, but to suppose that "the same rules of international morality, can obtain...between civilized nations and barbarians, is a grave error" (Mill 1867, 171-76; see Jahn 2005). In response, independent non-Western states sought to advance codification of international law, especially around sovereignty, and to undermine the "standard of civilization" as the price of entry to the club of independent states, thereby constraining common practices of gunboat diplomacy and intervention (Lorca 2014, 143-45).

For obvious reasons, therefore, "weaker states have always been the strongest supporters of the rule of nonintervention" (Krasner 1999, 21). Despite those clear benefits, small states also have recognized the corollary dangers of stringent norms of non-intervention, particularly for democracies. The notion of absolute sovereignty is challenged by the philosophical position that sovereignty resides not in the state but in the people. As expressed by Locke and Rousseau and advanced by the American and French Revolutions, popular sovereignty questioned the right of an unjust monarch to claim the authority to rule. Many Latin American constitutions in the nineteenth century enshrined this right to rebellion in both letter and practice (Sabato 2018, 89-121). Controversy persists over whether locating sovereignty in the people implied only the right of those people to revolt against their own state or went further to include the right of external states to intervene against those sovereigns who "render themselves the scourges and horror of the human race," as Vattel wrote (Glanville 2014, 214-15). Some authors identify in this history the idea of conditional sovereignty: that the right to rule is dependent on the "responsible" exercise of authority (Bellamy 2008, 19; Evans 2008, 34-37; Peters 2009, 514).

The theory and practice of precommitment have built on this foundation. Although state commitments that limit sovereign discretion are not unusual, precommitments to democracy and human rights differ, because the attenuations directly concern the prerogatives of ruling regimes vis-à-vis their own populations, not just foreign partners. Under democracy and human rights regimes or collectively adopted versions of R2P, states delegate adjudication and enforcement of aspects of domestic rule to international actors: regional organizations, the United Nations Security Council (UNSC), or a loosely defined "international community." As Simmons $(2009,3)$ notes, states' willingness to adopt such constraints "stands in contrast to a long-standing presumption of internal sovereignty."

Studies of R2P, human rights regimes, and democratic commitments are linked by a focus on how states' sovereignty claims conflict with the international protection of individual well-being within states. Despite that connection, international commitments to protect human rights, on the one hand, and to uphold democratic governance, on the other, emerged on different tracks. The inception of the contemporary international human rights regime is usually credited to the post-World War II Universal Declaration of Human Rights (Sikkink 2018, ch. 3), ${ }^{3}$ as well as the institutionalization of the European human rights system (Moravcsik 2000). R2P emerged from the international human rights tradition and movement, though it is very much a product of the post-Cold War world. Across different iterations, R2P proposals all reconceptualize sovereignty as legitimating external intervention under certain circumstances.

The formalization of international democratic commitments is thought to be even more recent. Although US leaders since Woodrow Wilson have invoked a universal right to democracy, attempts to create binding legal and normative frameworks for what Franck (1992) called "the emerging right of democratic governance" seemed to be a product of the post-Cold War world. Perhaps surprisingly, the literature on international democratic commitments places less emphasis on the implications for sovereignty, but similarly sees precommitments as a strategy to tie the hands of future, perhaps less democratic, leaders (Mansfield and Pevehouse 2006; Pevehouse 2002).

Despite their different historical trajectories, international commitments to democracy and human rights have both led to proposals for precommitment regimes as a response to the dilemma of sovereignty and international protections. Buchanan and Keohane (2011) argue that sovereigns can create exceptions to their immunity through the adoption of "precommitment regimes." If leaders voluntarily adopt commitments to protect human rights and maintain democratic governance, international enforcement would seem to support the sovereign will, instead of subverting it. In Buchanan and Keohane's proposal, "fragile democracies" - states ruled by governments that currently enjoy popular sovereignty but may be at risk of future coups, ethnic conflicts bringing abuses of human rights, and the like-could "enter into a contract" authorizing future intervention in their territory by selected "guarantor states" in case of their own incapacity or forceful removal $(2011,41,55)$.

Given IR's traditional emphasis on sovereign discretion, such invitations to intervention may appear unrealistic. However, various types of precommitment regimes operate in international relations today, including through global and regional commitments to human rights and regional accords on democracy in Africa, the Americas, and Europe. Buchanan and Keohane's proposal finds support in Moravcsik's (2000) work on the adoption of European human rights regimes. Though many scholars have seen human rights commitments merely as "empty promises" (Hafner-Burton and Tsutsui 2005), agreements like the Rome Statute that created the International Criminal Court appear to create real transfers of sovereign 
discretion by states that could find their leaders under prosecution (Simmons and Danner 2010).

International precommitment regimes have faced two classes of problems. First, although precommitment is offered as a solution to the problem of legitimacy, enforcement actions are still likely to be challenged. The precommitment's relationship to sovereign discretion and immunity is not clear-cut, given problems of time-inconsistent preferences. Simply put, can the sovereign change its mind about precommitments, and what effect does that have on the legitimacy of actions to enforce them? Second, precommitment regimes face challenges of institutional design for decision making and enforcement. These problems are intimately connected: without consensual mechanisms, actions under precommitment regimes are unlikely to be granted legitimacy by the relevant community of states, let alone the target of enforcement. With the existing international machinery often stymied by UNSC vetoes and regional objections, some scholars have proposed that legitimacy come instead from agreement among a league of democracies (Daalder and Lindsay 2007), with Kosovo often cited as an example. However, nonmembers and nondemocracies are likely to oppose vehemently the legitimacy of such actions; for example, Russia opposed the Kosovo intervention.

UNSC approval is a legal obstacle to the use of force, but it need not stop all actions related to precommitments. As Glanville (2017) argues, nonmilitary preventive mechanisms may often provide greater benefits for human rights at lower costs. Similarly, the (uneven) enforcement of democratic and human rights clauses usually relies on reputational mechanisms as opposed to material or coercive sanctions (Donno 2010). However, emphasizing means short of force is no guarantee that sovereignty will not be used as a shield. Nonmilitary pressure is regularly denounced as an unwarranted intrusion into internal affairs, a position adopted by medium-sized states like Venezuela and Israel and major powers like China and Russia. States are jealous of their sovereignty in the face of international organization reports, court decisions, and economic sanctions. Agreed-on mechanisms that ensure both restraint and consistency are crucial to reducing this opposition.

Proposals by Buchanan and Keohane (2011) and Ikenberry and Slaughter (2006) focus on actions by great powers, especially the United States, and on violations in weak states. This focus risks missing the other side of the equation: constraints on intervention. A region must fulfill its commitments to support neighboring populations, whereas enforcing states must commit to acting only for the reasons and through the means established in the terms of the precommitment. Reciprocal precommitments from the region and the great power assuage some of the concerns of neocolonialism dressed in humanitar- ian garb (e.g., Ayoob 2002). This combination, highlighted in the Larreta Doctrine, transforms intervention for human rights or democracy into a call for collective commitment that avoids numerous pitfalls inherent in forceful democracy promotion. Because the region gave sovereignty and non-intervention pride of place, Latin America's debates around "collective intervention" offer a rich source of inspiration on balancing the desire to protect rights and (in some cases) democracy with powerful interests, norms, and arguments in favor of strong sovereignty. We now turn to the evolution of these debates in the Americas.

\section{Inter-American Divides on Sovereignty, Rights, and Intervention}

Latin American diplomacy and international jurisprudence have long emphasized sovereignty and non-intervention. Many of the region's best-known diplomats-Calvo, Drago, Estrada - are associated with doctrines that seek to reduce external intrusion in domestic affairs. Likewise, crucial Latin American diplomatic events, such as participation in the 1907 Hague Conference and the 1933 Montevideo Convention on the Rights and Duties of States, emphasize sovereignty and juridical equality through which "Latin Americans transformed the structure of international law" (Lorca 2014, 304-5). As early as the 1860s, Argentine jurist Carlos Calvo began to campaign for an absolute prohibition on diplomatic or military intervention for debt collection, then a routine practice for North Atlantic powers. At a time when most European countries and the United States argued that their nationals deserved preferential treatment and effective extraterritorial sovereignty, Calvo countered that investors should not turn to their home governments for satisfaction but to the local courts (Calvo 1877). He was supported by the Argentine foreign minister Luis Maria Drago, who in response to the Venezuela crisis of 1903 called for an absolute prohibition on military intervention in "the territory of American nations" (Drago 1903). The United States, however, thwarted the adoption of the Calvo and Drago principles at a series of Pan-American conferences. Instead, Latin American governments incorporated Calvo's principles into the language of contracts with foreign corporations, legal statutes, and national constitutions in the form of the so-called Calvo Clause, requiring parties to be bound by the host country's judicial system. The Second Peace Conference at The Hague in 1907 adopted an attenuated version of the Drago Doctrine.

Alongside the Argentine tradition, revolutionary Mexico also promoted strict non-intervention as a principle of international law. Venustiano Carranza, Mexico's first constitutional president after the revolution of 1917, issued a doctrine holding that all nations are equal under the law, and thus there could be no legitimate intervention 
—without exceptions. By 1930, Mexican foreign secretary Genaro Estrada extended the principle from nonintervention to non-interference by declaring that Mexico would no longer make judgments about the nature of foreign governments, whether they came to power legally or extralegally. The Estrada Doctrine was invoked by other countries following the model. These currents culminated in the hemisphere-wide adoption of strict nonintervention at the 1933 Montevideo Conference, which resolved that "no state has the right to intervene in the internal or external affairs of another" - a resolution signed by the United States.

However, a parallel current recognized that sovereignty and absolute non-intervention, too, posed certain dangers. Although they were central to the region's diplomatic and international legal thinking, the claims described earlier came with caveats-even from those who proposed them. Calvo, a lifelong champion of the principle of non-intervention, nevertheless argued that English, French, and Russian intervention to put a stop to "the barbarities of the Turks" against Greek rebels was "fully justified in the light of the principles of international law" (1877, 303-4). Well before Rodríguez Larreta, Latin American diplomacy sought to use prior agreements to square sovereignty with intervention for rights protection and to address the related problem of colonial practices that ignored the sovereignty of poor countries. Concerned about instability generated by frequent uprisings and coups at the turn of the twentieth century, Carlos Tobar, the former foreign minister of Ecuador, argued that Latin American states should be prepared to collectively deny recognition to governments that come to power by violence against the constitutional order. The Tobar Doctrine was incorporated in the style of a precommitment regime, albeit without developed mechanisms for implementation, into a treaty among the Central American states in 1907 and another among the Andean countries in 1911 (Fabela 1991).

Although non-intervention remained the prominent Latin American discourse, as seen in Pan-American conferences throughout the 1920s and 1930s (Lorca 2014; Scarfi 2017), a budding generation of Latin American democrats during those same years looked toward international commitments to advance their struggle against authoritarianism. Victor Haya de la Torre, a Peruvian democrat with a continental following, argued in 1941 that "violations of democratic rights demanded a common response" (qtd. in Schwartzberg 2003, 65). During a notable democratic interregnum in August 1944, Cuban diplomats argued, "An attenuation of the unrestricted concept of sovereignty would constitute, in the judgment of the Government of Cuba, a great step forward to advance this end." ${ }^{4}$ They urged that this effort be supported by a Declaration of the Rights and Duties of Nations and of the International
Rights and Duties of the Individual in line with the Atlantic Charter.

Although globally most attention has been paid to precommitments to halt violations of human rights, in the Americas, the notion of regional precommitments regarding democracy has long sparked significant debate. Hawkins and Shaw (2007) note that objections to the legalization of democratic commitments-long prevalent in mere declaratory form - were contextualized in terms of the defense of sovereignty. The Americas seemed to move to a new equilibrium after the Cold War, with a collective democratic commitment made in OAS Resolution 1080 in 1991 and culminating in the 2001 signature of the Inter-American Democratic Charter (IADC). The IADC treated democracy as a right, and "new, more stringent democratic norms" gave the inter-American community a greater enforcement role (Heine and Weiffen 2015, 6162), effectively "sanctioning external intervention for principled reasons" (Feldmann, Merke, and Stuenkel 2019, 451). Although the application of democratic commitments has been uneven, and incumbents continue to claim a sovereign shield even as they backslide on earlier state commitments to democracy and human rights, the Latin American tradition of seeking to balance sovereignty and democracy protection continues into our own time.

The following section recounts the context, emergence, support for, and eventual defeat of the Larreta Doctrine. It focuses on how participants in this debate understood the relationship of precommitments to sovereignty; on issues of legitimacy and processes of decision making; and on the balance between great powers and small vulnerable states.

\section{The Larreta Doctrine}

On October 19, 1945, in the context of an apparent Argentine drift toward fascism, Uruguayan foreign minister Eduardo Rodríguez Larreta handed US ambassador William Dawson a note that challenged the core assumption of twentieth-century Latin American diplomacy. The sacrosanct principle of non-intervention, Rodríguez Larreta wrote, should not be used to mask notorious and repeated violations of elementary human and civil rights, which were a matter of legitimate interest for other states. Instead, "parallelism between democracy and peace" should henceforth be advanced as an inter-American norm. Any action, to be sure, "must be collective" (qtd. in FRUS 1945, doc. 126). Secretary of State James Byrnes, who understood this as an anti-Argentine measure, responded with enthusiasm, promising that the United States would "immediately and vigorously support him in all of the American capitals" if Rodríguez Larreta were to circulate his proposal "as a basis for joint action" against Argentina (FRUS 1945, doc. 127). Rodríguez Larreta replied that he planned to introduce the measure to the inter-American system, but without mention of Argentina 
to avoid provoking his larger neighbor and because he believed the issue was of broader significance (FRUS 1945, doc. 128). ${ }^{5}$

One month later, Rodríguez Larreta sent all the American nations a longer note, which reshaped his initial message into a proposal for precommitment. ${ }^{6} \mathrm{He}$ called for an endorsement of "multilateral collective action" to sustain democracy and the "rights of man and of the citizen." Past declarations were insufficient without collective commitments and procedures to support them. In short, "the necessity of a system of international protection of those rights is proclaimed." Governments enjoying popular legitimacy would grant previous sanction for actions to protect endangered democracies and to forestall or halt egregious violations of human rights; as such, enforcement would not violate true sovereignty. Moreover, Rodríguez Larreta wrote to the State Department that his plan would require a supermajority vote in a regional system of juridically equal states to authorize any action, which would be permitted under the UN Charter's Article 51, but it would not require separate UN approval (FRUS 1945, doc. 133). The formula sought to square the dilemma between highly valued sovereign equality and the principles of regional democracy and rights.

Rodríguez Larreta's proposal was in line with a Uruguayan diplomatic tradition of seeking to punch above the country's bantamweight by offering innovations to international law that would help protect small states. Sergio Abreu described Uruguay's international policy as "increasing the country's credibility and prestige in inverse proportion to its geographical, military, and economic presence" (qtd. in Casal Tatlock 1997, 7). At the Second Peace Conference at The Hague in 1907, Uruguay proposed a system of compulsory, supranational arbitration to replace interstate conflict. In 1920, noting the weakness of the League of Nations in the absence of the United States, Uruguayan president Baltasar Brum advanced a proposal for an American League of Nations that would replace the unilateralist Monroe Doctrine with an egalitarian organization for collective defense that would embed US power in a multilateral system (Scarfi 2017, 82-83). At the PanAmerican Conference in Havana in 1928, Uruguay introduced a resolution calling on member states to determine when exceptions to the non-intervention principle should be permitted; they would then be adjudicated by an international tribunal. Rodríguez Larreta expressed the hope that Montevideo might play a role in Latin America comparable to Geneva in Europe. ${ }^{7}$ Tiny Uruguay, flanked by the South American powerhouses of Argentina and Brazil, used international diplomacy to try to escape a Thucydidean fate. In addition, liberal Uruguay evoked the Kantian tradition that republics are less warlike than nonrepresentative regimes. Rodríguez Larreta's predecessor, José Serrato, told the San Francisco conference in
1945 that "Uruguay, as a small country without military power, knows that the destiny of its liberty and the full exercise of its sovereignty... rest on the universal imperium of democratic norms" (qtd. in Casal Tatlock 1997, 218). The notions that democracies would not go to war with one another and that war was a threat to democratic survival, especially for small states, came together in Rodríguez Larreta's call for a system of collective defense of democratic and human rights. This system would protect Uruguayan security by binding the United States and Argentina to multilateralism while advancing the creation of a peaceful, democratic neighborhood.

Although Rodríguez Larreta's diplomatic notes called for "multilateral action" and not "intervention," the foreign minister contrasted his proposal to absolutist principles of non-intervention, calling for a "harmonization" of conflicting principles that presumably required a reconceptualization of sovereignty. Regardless, Latin American skeptics saw the Larreta Doctrine as formalizing a road to military intervention. A week after issuing his diplomatic circular, Rodríguez Larreta clarified publicly that the proposal was not intended to invoke military means. There was "an infinite range of gradations starting with softer measures. . . according to the scale that circumstances dictate" (qtd. in Casal Tetlock 1997, 57). He echoed today's frustrations, though, saying that American states could not cite non-intervention and then stand by "with arms crossed" while others violated "essential and sacred" principles.

Many of the replies by American republics, issued in December 1945 and January 1946, expressed hesitation about weakening non-intervention. In a message from February 2, 1946, Rodríguez Larreta responded to "the resistance that has been raised, emanating from the fear that the principle of non-intervention would be modified." His revised proposal sketched the mechanism for enforcement: any denunciation of a country for violating human or democratic rights must be made by a minimum of three countries; at least two-thirds of countries represented at a meeting of the Pan-American Union must vote in favor of any measures; and these measures must be peaceful, with a maximum sanction of breaking of diplomatic relations as "one of the recommended measures of exercising collective action, and surely, one of the most efficient." If that proved insufficient, the issue would go before the UNSC or the General Assembly. ${ }^{8}$ In its essence, his proposal emphasized regional collective action, the illegitimacy of unilateral intervention, and a precommitment to protect popular sovereignty.

Following a pattern common to scholarship on USLatin American relations, earlier accounts have suggested that, despite its name, the Larreta Doctrine was just one more US project. One author asserts, "Spruille Braden, who had left Buenos Aires to become assistant secretary of state for American republic affairs, induced the Uruguayan 
foreign minister, Eduardo Rodríguez Larreta, to issue an appeal for collective intervention to ensure democracy and respect for human rights in the Americas" (Langley 2010, 164; emphasis added). Another suggests it might as well have been called the Braden-Larreta Proposal, "since it appeared to have been stimulated by the new Assistant Secretary of State for American Republic Affairs" (Kesler 1985, 261). At the time, the opposition Uruguayan newspaper El Debate questioned why Rodríguez Larreta wanted to turn Uruguay into the tip of the spear for US intervention in Argentina (El Debate 1945). ${ }^{9}$ The Argentine government was also suspicious. Foreign Minister Juan Isaac Cooke described the "transcendental" achievement of consensus on non-intervention as the product of a century of effort that Rodríguez Larreta now threatened to undo. Given the disproportionate power of the United States, Cooke concluded, if the proposal were to be implemented, "the control of the intervention policy would fall upon the United States." ${ }^{10}$ His point has clear corollaries in today's concerns about great power exceptionalism and the justification of power politics in the name of democracy and human rights.

Although Braden did welcome Rodríguez Larreta's proposal, the State Department did not initiate it (FRUS 1945, docs. 129, 130), ${ }^{11}$ and it diverged significantly from the traditional US approach to the region. By embedding any potential pressure or sanction in a multilateral process requiring a supermajority of the region's states, the Larreta Doctrine would have hamstrung US unilateralism by strengthening institutional binding mechanisms. The Uruguayan tried to allay concerns that his proposal would undo the hard-won intervention prohibition extracted from the United States after decades of Latin American efforts (Friedman and Long 2015), culminating in USsigned resolutions at inter-American conferences at Montevideo in 1933 and Buenos Aires in 1936 that asserted that "no state has the right to intervene in the internal or external affairs of another." Rodríguez Larreta argued that his proposal would never alter this norm, because it disallowed any single state from intervening unilaterally. To the extent that his insistence on using only peaceful instruments of intervention was genuine, Rodríguez Larreta also intended to eliminate armed intervention as practiced by Washington, a source of Latin America's obsession with absolute sovereignty. Taken together, the ban on military intervention combined with the establishment of a multilateral requirement for collective actions would have created a counterweight to the exercise of US hegemony.

\section{Reactions to Larreta}

Within two months, all American states had replied formally to the proposal, except Argentina, which denounced it publicly. Their replies ranged from strong support to vehement opposition based in norms of non- intervention. Uruguay tried to square its proposal with that concern in several ways. Montevideo's El Pais (1946a), Rodríguez Larreta's press outlet, argued that in light of the Good Neighbor Policy, "Now, no one thinks about unilateral interventions. That which was once a threat has completely dissipated. The principle of nonintervention belongs to public inter-American law and is incorporated into the conscience of the government and people of the United States." ${ }^{12}$ Although the proclamations of the Good Neighbor era might have satisfied Uruguayan concerns, US power still looked quite different to states in its immediate vicinity. As a Mexican critic charged, the proposal represented nothing less than a doctrinal shift from non-intervention to "neo-intervention" (Paniagua 1945). Despite that, the Larreta Doctrine garnered support from several fragile democracies near the United States, indicating that under the right circumstances, even vulnerable countries may be willing to precommit. We briefly examine the responses of two key supportive countries: the United States as the crucial great power and Guatemala as a supportive emerging democracy. Colombia represented an opposing democracy (a position shared by Chile). Mexico and Brazil played crucial roles as the largest Latin American states, both ultimately in opposition. Unlike one-party Mexico, with its history of US intervention, Brazil's opposition, expressed while it was in the midst of its own democratic transition, is surprising in light of arguments that transitional leaders will seek to lock in their successors.

United States. The strongest power in the hemisphere immediately embraced the idea, initially in the hope of using it "as a basis for joint action in relation to the Farrell Government" in Argentina. ${ }^{13}$ The Truman administration believed the government of Edelmiro Julián Farrell and Juan Domingo Perón represented a node of Axis ideology that threatened postwar Allied interests in Latin America. Rodríguez Larreta hurriedly informed the State Department that there should be no mention of Argentina in a discussion of principles. ${ }^{14}$ The two countries coordinated their diplomatic and press campaigns on behalf of the proposal, with Secretary of State James Byrnes careful to instruct US diplomats not to give the false impression that it was a US initiative. ${ }^{15}$ Once the debate was under way, Byrnes stated his "Government's unqualified adherence to the principles enunciated" by Rodríguez Larreta. ${ }^{16}$ US officials were heartened to see some smaller states such as Costa Rica, Panama, and Guatemala respond positively, "notwithstanding the fact that those states might have been expected to be the most interested in maintaining the view that a country's internal affairs are not susceptible of consideration by other countries, much less of collective action by other countries." ${ }^{17}$ The doctrine seemed to present a timely opportunity to rally regional opposition to Buenos Aires, even as the United States was taking unilateral (and ultimately 
counterproductive) steps against Argentina at odds with the Larreta Doctrine's multilateral foundation.

Guatemala. The proposal received warm support from a country that shared Uruguay's position as a relatively precarious democracy, but had greater concerns about US intervention. Guatemala had emerged from generations of dictatorship the year before, and its president Juan José Arévalo faced hostility from nearby authoritarian rulers such as Tiburcio Carías Andino of Honduras and Anastasio Somoza García of Nicaragua. Arévalo suffered multiple coup attempts by his own military. At the February 1945 Chapultepec Conference, Guatemala proposed that the American republics agree not to recognize governments that came to power through coups against democratic regimes. Guatemalan foreign minister Guillermo Toriello praised the Uruguayan proposal as "entirely in agreement with the modern principle of international interdependence which replaces the archaic concept of absolute sovereignty of states; being the only manner possible to protect internationally the rights of man and to achieve a truly democratic world." ${ }^{\prime 8}$

Guatemala exemplifies a weak state that saw potential protection in Rodríguez Larreta's proposal against antidemocratic domestic and neigboring foes. Several other fragile democracies, including Cuba and Venezuela, enunciated similar supportive rationales, despite precedents of US and other great power intervention. Small states whose sovereignty had been repeatedly violated saw the benefits of a system of constraints on unilateral great power action tied to a regional mechanism to strengthen democracies against the possibility of military coups and interference from authoritarian neighbors.

Colombia. The Colombian response to Rodríguez Larreta, in contrast, foreshadowed many concerns about R2P expressed by the Global South. Different forms of government should be respected, and under different regimes "it is very difficult, if not impossible, to guarantee the essential rights of man." It is better, then, that any policy should safeguard "small and defenseless nations." Colombia even opposed the sorts of "investigative commissions" that might be necessary to ascertain conditions on the ground, because they "would put an end completely to the concept of sovereignty." 19 With an apparently stable system of alternating two-party rule, Colombia's political culture in 1945-46 was less sensitive to acute fears of possible coups d'état, even as its history of civil violence may have invited unwanted international scrutiny. Having lost its most prized asset when the United States intervened to help its Panamanian province secede, Colombia was not willing to see absolute strictures against intervention watered down in any way. It coordinated its opposition with Chile, which likewise had a long tradition of oligarchic civilian rule that was democratic in form. ${ }^{20}$

Mexico. Perhaps no state resisted Rodríguez Larreta as forcefully as Mexico; its opposition was probably the death knell for the proposal. Unlike Brazil, which hesitated to make a formal response, Mexico answered Uruguayan proposals quickly and vigorously. The official rejection was communicated on December 10, 1945, arguing that "the principle of non-intervention. . .should not be weakened in any form." Doing so would risk unleashing "even greater evils" than those that Rodríguez Larreta hoped to contain. ${ }^{21}$ Mexican opposition created useful cover for smaller states in the hemisphere-especially those with even weaker democratic credentials than Mexico-to oppose the United States. ${ }^{22}$ The Dominican Republic, Haiti, Honduras, and Nicaragua — each with living memories of interventions, occupations, and kingmaking by US Marines-quickly rejected the proposal; Panama expressed strong reservations. El Salvador denounced it as "a dangerous precedent." 23

However, as a government still clinging to its revolutionary credentials and one that had enshrined the panoply of rights in its constitution, Mexico's opposition required a delicate balance. The Mexican Foreign Ministry published a 44-page memorandum in February 1946 deconstructing the Uruguayan proposal. Mexico's declarative support for democracy at home and human rights in international forums did not extend to altering the principle of non-intervention. Although agreeing that international law posed ever-larger constraints on domestic politics, Mexico argued that "actually, it would be prejudicial and against the most recent international instruments to propose a violation of said internal jurisdiction, even by means of collective action." 24

Rodríguez Larreta sought space for cooperation with Mexico, noting a seeming openness to responding to rights violations with collective ruptures in diplomatic relations. Even there, Mexico indicated that the matter should be dealt with by the United Nations. ${ }^{25}$ Mexican foreign secretary Francisco Castillo Nájera clarified the country's opposition in a letter to Brazil, listing "the motives for which Mexico adopts its non-interventionist doctrine, which above all respects the sovereignty of states" as the reason for rejecting the Larreta Doctrine.

Brazil. Engaged in its own electoral transition from the long authoritarian rule of Getúlio Vargas, Brazil was slow to make a formal reply. However, its diplomats were skeptical of the proposal from the beginning. It was "impeccable and even magnificent in form," but "it is still very dangerous in essence given its concern with the sovereignty of weak states, which if it were approved, would be at grave risk regarding their sovereignty and liberty." ${ }^{26}$ Brazil's ongoing transition and entrenched doctrinal emphases on both sovereignty and friendliness with the United States created a dilemma. It could embrace the Larreta Doctrine, given US support, but that could cause trouble with the still influential Vargas. Conversely, it could reject the doctrine and risk raising questions about its commitment to a democratic 
transition. Itamaraty (the palace housing the foreign ministry) communicated quietly with US ambassador Adolf A. Berle, a major proponent, that the proposal "would not be advisable at this moment," but that it was open to greater consultations (FRUS 1945, doc. 146).

\section{Precommitment and Intervention}

For all his protestations that he never intended to weaken the stricture against military intervention, Rodríguez Larreta still made a point of arguing that the Latin American norm of absolute sovereignty had gone too far. In a press conference, he criticized "this concept of a sovereignty with an almost divine essence, hermetic, intangible, and untouchable," which had been paired with a principle of non-intervention that had become "an impenetrable veil behind which countries may commit any kind of attack" (qtd. in Casal Tatlock 1997, 57). His proposal intended to "defend the principle of nonintervention and to repudiate all interventions that are isolated [i.e. unilateral] and presumably self-interested; but to create an international tribunal that can prevent the abuses and scandals that can take place behind the shield of this principle of non-intervention" (213).

After Rodríguez Larreta left office, Uruguayan foreign minister Mateo Marques Castro $(1947,12)$ explained that the Larreta Doctrine "does not imply-ever-the intervention of one State or group of States in the affairs of another." Protecting human rights "requires, for its application, the previous existence of a norm freely agreed to on the basis of a juridical order accepted by the Parties." The Uruguayans were building on the notion of precommitment established in South American traditions of international law. In his 1944 legal treatise, Daniel Antokoletz of Argentina defined intervention as illegitimate unless it was permitted by a preestablished treaty. This applied, for example, to the defensive preservation of the state (conservación in Spanish legal writing). Chile's Alejandro Álvarez's text on principles of "modern international law," approved by the Academia Diplomática Internacional, the Unión Jurídica Internacional, and the International Law Association, included Article 22: "In the absence of a special juridical title, no State has the right to intervene, especially by force, in the internal or external affairs of another State, without the consent of the latter, even when the persons or possessions of its nationals are endangered. Collective intervention by all States or a group of them is permitted according to the dispositions of the charters of global, continental, or regional organizations" (Álvarez 1944, 37-40; emphasis in original). During a visit to Montevideo, Brazilian jurist Levi Carneiro argued that the Larreta Doctrine "was not a precipitous and imprudent innovation: on the contrary, it was the crystallization of a doctrinarian movement that has been fortified and intensified, characterizing the new phase of international law." He cast the Uruguayan proposal as an international version of the revolutionary Declaration of the Rights of Man: "certain fundamental rights, certain 'human rights' as has already been said, need a collective international guarantee, just as has happened with 'social rights' relative to working conditions" (qtd. in El Pais 1946b). ${ }^{27}$ Isidro Fabela, a long-time adviser on international law to the Mexican Foreign Ministry, took note of these arguments while cautioning against the danger of an interventionist power (read: the United States) taking advantage of multilateral mechanisms to pressure smaller powers to go along. However, even Fabela, a staunch defender of nonintervention, made his strongest case against humanitarian intervention when decided "unilaterally by the same power that executes it, because this power then becomes both judge and jury" $(1991,150)$. If the Larreta Doctrine had not convinced, it would still seem to leave open the possibility of collective action if a precommitment mechanism could be developed to address the core concerns of the critics.

\section{Defeat and the Denouement}

As early as December 14, 1945, US diplomat John Moors Cabot privately concluded that "the Rodríguez Larreta note has already boomeranged badly throughout the Hemisphere." ${ }^{28}$ By the middle of 1946, the proposal had faded from view. In the summary of the debate published by the Pan-American Union in 1946, 13 states opposed the Larreta Doctrine while 8 supported it. It was left off the agenda for the Rio Conference in 1947. This quick defeat, despite the support of the United States, consigned the Larreta Doctrine to the status of historical curiosity. Was its influence so fleeting? The debate on rights and how to secure them continued over the next several years as the inter-American system took shape. Rights advocates in that debate deployed similar language, and the Larreta Doctrine's supporters pushed for greater collective responsibilities in the Americas for the protection of human rights and democracy. This led to the inclusion of seemingly contradictory impulses in the founding documents of the postwar inter-American system (Sikkink 1996); some of these were taken up again by international democracy and human rights advocates decades later. Rodríguez Larreta's proposal did not cause these later changes, but his influence in the postwar moment left a legacy in the inter-American system.

Rodríguez Larreta first proposed his doctrine during the preparations for an inter-American conference on reciprocal defense. When the conference finally met in Rio de Janeiro in September 1947, the American states agreed on a collective defense pact. Although this pact is often treated as an early indicator of Cold War tensions in the Americas, it was also an extension of wartime cooperation that emerged more directly from the 1945 Inter-American Conference on the Problems of War and Peace (the Chapultepec Conference) than from US-Soviet rivalry. 
While much of the debate in the postwar conferences surrounded economic issues, some delegations continued to press for greater attention to human rights and democracy, including advocacy for a system that went beyond declarations of principles. In 1946, the Governing Board of the Pan American Union approved a draft Declaration of the Rights and Duties of American States, which included, "It is the duty and obligation of each American State to respect and promote the rights and liberties consecrated in the Declaration of International Rights and Duties of Man, without distinction of race, sex, language, or religion." ${ }^{29}$ The Inter-American Treaty of Reciprocal Assistance (1947) bears the imprint of the Larreta Doctrine and contemporaneous debates - though in the preamble and not in the binding clauses. The treaty says, "Peace is founded on justice and moral order and, consequently, on the international recognition and protection of human rights and freedoms, on the indispensable well-being of the people, and on the effectiveness of democracy for the international realization of justice and security."

The next year, at the Ninth International Conference of American States in Bogotá, the delegations created the Organization of American States to provide a more robust mechanism for regional consultation and decision making and signed a separate treaty on the peaceful settlement of disputes. The conference approved a positive vision of rights in the American Declaration on the Rights and Duties of Man (ADRDM), as well as an anticommunist resolution on "The Preservation and Defense of Democracy in the Americas." The ADRDM is best known for its enunciation of civil, social, and economic rights and as a precursor familiar to the authors of the Universal Declaration of Human Rights. It places the onus for the protection of these rights at the national level "as best suited" to contemporary conditions. Following the Mexican dismissal of the Larreta Doctrine that left open the possibility of future action, the declaration adds that the American states "should increasingly strengthen that system in the international field as conditions become more favorable." Though the OAS Charter includes several references to promoting representative democracy and an article that "the State shall respect the rights of the individual and the principles of universal morality," it prioritized sovereignty, non-intervention, juridical equality, and territorial inviolability. Clearly, in the late 1940s, the moment was not ripe for precommitment as envisioned in the Larreta Doctrine.

This would seem to be the final repudiation of Rodríguez Larreta. Indeed, the OAS Charter's Article 19 closed the Larreta loophole by updating the resolutions from the 1930s asserting that "no state" may practice intervention-which Rodríguez Larreta argued left open the possibility of collective intervention-to read "no state or group of states." However, some of Rodríguez Larreta's proposal lived on in the charter. In the original 1948 version, it included Larreta-like language: "The solidarity of the American States and the high aims which are sought through it require the political organization of those States on the basis of the effective exercise of representative democracy." Later in the document, it reads, "The State shall respect the rights of the individual and the principles of universal morality." However, this language was contradicted by a focus on inviolable sovereignty elsewhere in the charter and, more importantly, by decades of comity with authoritarian practices. The influence of the Larreta Doctrine was more evident in the ADRDM and concurrent, though stillborn, proposals for inter-American human rights organs (Cabranes 1967: 1161-62).

By 1950, the democratic tide in the Americas had begun to recede, a trend the United States advanced in 1954 when the CIA helped orchestrate a coup against the elected successor to the Guatemalan president who had forcefully supported the Larreta Doctrine. The American Declaration and contemporary texts, closely tied to the Larreta Doctrine and its proponents, again gained relevance in the Americas starting in 1959 as rights violations and foreign meddling by Dominican dictator Rafael Trujillo came to light. In the Declaration of Santiago that year, the foreign ministers of the Americas echoed Rodríguez Larreta's argument about the parallelism between democracy and rights domestically and interAmerican peace (Cabranes 1967: 1164), while carefully emphasizing principles of non-intervention (OAS 1959, 1960). While not binding, that declaration emphasized that "anti-democratic regimes" violated the OAS Charter and caused "widespread disturbance" in the region. The actions of 1959-60 added another layer to the postwar foundations with the creation of the Inter-American Commission on Human Rights (IACHR; Engstrom 2016; Goldman 2009), which was established with direct reference to the ADRDM. Indeed, the IACHR claimed, somewhat controversially, that the 1948 declaration and reference to "human rights" in the OAS Charter gained legally binding status; these texts both emerged from the immediate context of the Larreta Doctrine debate. Charles Fenwick (1964), supportive of Larreta in 1946, later reflected on these events to suggest "inter-American collective action" on the nonrecognition of despotic governments.

Regional efforts on human rights were largely dormant —and increasingly separate from democracy protectionuntil 1978 when the long-awaited American Convention on Human Rights went into force during a notorious period of human rights violations under military governments (Engstrom 2016). Despite several other proposals from Latin Americans, regional commitments to democracy waited until the end of the Cold War, when all American states except for Cuba signed the Santiago declaration in 1991. A decade later, this was superseded 
by the Inter-American Democratic Charter. Effective since 1997, Article 9 of the revised OAS Charter echoes the Larreta Doctrine: it provides for the suspension of states whose democratic governments have been toppled by force, after consultations and noncoercive attempts at restoration, by a two-thirds vote of the OAS General Assembly (Cooper and Legler 2001). The charter's chapter on "Strengthening and Preservation of Democratic Institutions" also echoes Rodríguez Larreta's language. The text studiously avoids the term "intervention," but includes provisions for states to appeal to the OAS if their democratic systems are at risk; more controversially, it states that the OAS may take actions "for the preservation of the democratic system and its strengthening" (OAS 2001, chap. IV). These were imperfect and incomplete steps toward giving weight to the democratic promises made in the founding documents of the inter-American system (Heine and Weiffen 2015), though the ambiguity and weakness of their mechanisms for collective response have been laid bare by the erosion of democracy and human rights in Venezuela and elsewhere.

\section{Conclusions}

The tension between non-intervention and international protections has been particularly prominent in interAmerican relations. Today, it animates regional debates over the response to crises in Venezuela and Nicaragua, as well as over the role of international anticorruption commissions in Guatemala and Honduras. Often the debate is seen along simplified lines: the United States, operating from a position of uncontested power, favors easing restrictions on interventions in defense of human rights and democracy or, more critically, on interventions to pursue its interests under the guise of human rights and democracy. Conversely, Latin Americans are tireless champions of sovereignty and non-intervention as the last recourse of relatively weak states. This pattern has largely characterized-and, to some degree, limited-US-led order-building in the Americas at least since World War II, according to many narratives. The major exception to this was the immediate post-Cold War era, in which liberal commitments expanded across the hemisphere for several years before entering into a prolonged and deepening retrenchment. The history of the Larreta Doctrine adds significant nuance to this understanding. Despite its ultimate failure, the proposal was an innovative attempt to use international precommitment as a bridge between the traditional Latin American insistence on non-intervention and goals of advancing democracy and protecting human rights.

Recent proposals for precommitment regimes in democracy and human rights should be informed by the Larreta Doctrine and debate. If precommitment regimes are to be accepted and perceived as broadly legitimate, greater attention is required to the interests of small and vulnerable states, especially the importance of reciprocal commitments among neighbors and constraints on great powers. The major objections to the Larreta Doctrine prefigured the lines of opposition to international action in response to rights and democratic violations a halfcentury later, among both scholars and practitioners. These included the protection of sovereignty, a defense of pluralism in international society, skepticism about the universality of rights, legitimizing the vulnerabilities of small states, and the related practical implication that the responsibility-and therefore decision-for intervention would fall to the greatest powers. Rodríguez Larreta's version of precommitment offers a tripartite commitment that is more attuned to the concerns of the less powerful.

Small and vulnerable states might agree more readily to the sort of precommitment regime that Buchanan and Keohane (2011) proposed, if it were supplemented in the ways the Larreta Doctrine suggests. In a critique of Buchanan and Keohane, Hehir (2011) implied that only states that are unlikely to experience breakdown would commit. Most interesting in that sense are the stances adopted by Uruguay, Guatemala, and Cuba. These small states came close to the precommitment ideal, yet they supported the doctrine despite the very real possibility of great power intervention. Their precarious democracies faced threats from within (coups and quasi-fascist opponents) and from without, including threats and interference from authoritarian neighbors. The protection of democracy - and therefore the defense of popular sovereignty - in small and vulnerable states would be advanced by this regional precommitment. This logic suggests the utility of a voluntary precommitment regime, even one that is not universal in character, with a clear process of decision making. That Uruguay crafted the proposal with one eye on a threatening Argentine government suggests that small states might see precommitment regimes as a source of regional as well as domestic stability. Guatemalan support of the Larreta doctrine provides another telling counterexample of a state that faced immediate internal and regional challenges to democracy-and would later suffer unilateral US intervention with ruinous consequences. Rómulo Betancourt, twice the leader of Venezuela's fragile democracy, consistently advocated regional democratic precommitment mechanisms. These countries' positions were shaped by external threats from neighbors, domestic coup threats, and the looming great power. Larreta-style precommitment helped balance those pressures.

The logic of Larreta precommitment foreshadows that of African and Latin American states decades later when they committed to the International Criminal Court, despite the foreseeability of indictments against their citizens and even leaders or of commitments to democratically dense regional organizations (Pevehouse 2002). Serbin and Serbin Pont (2015) observe that "the apparent 
dichotomy between 'champions' and 'sceptics' is often blurred," notably in Argentina's recent record of opposing US intervention while promoting R2P principles in the regional system (see also Feldmann, Merke and Stuenkel 2019). The African Union Constitutive Act went even further in endorsing collective intervention by the regional organization, though for a narrower set of gross violations of human rights. Its Article $4(\mathrm{~h})$ includes "the right of the Union to intervene in a Member State pursuant to a decision of the Assembly in respect of grave circumstances, namely: war crimes, genocide and crimes against humanity," though this has never been invoked (Makinda and Okumu 2007; Mboya 2009).

Questions of discretion and process continue to bedevil these rights and democracy protection regimes, especially because they raise doubts about procedural legitimacy and highlight practical difficulties in responding to any given crisis. The Larreta Doctrine offered several innovations regarding process. First, it shifted decisions and actions to a regional context-a move later echoed in diplomatic practice. This fit with contemporary Latin American efforts to buttress the inter-American system within the new global institutional order. Indeed, Serbin and Rodrigues (2011) argue that the Latin American example shows that regional organizations can play a special role in the implementation of rights protections, given their mechanisms for the peaceful resolution of interstate conflicts. At the same time, the Larreta process would avoid the inaction caused by the superpower vetoa problem that Latin American diplomats foresaw, warned against, and opposed before and during the 1945 San Francisco conference. The key elements are regional specificity, previously agreed and transparent standards, an emphasis on early preventive diplomatic measures, and collective supermajoritarian responsibility, couched in language reaffirming the illegitimacy of unilateral and extraregional intervention that together are the bane of formerly colonized regions of the world.

Finally, how should states with different levels of power relate to collective decisions and actions? The postwar Americas were as marked by power asymmetries as the current context, and concern about the interventions of great powers was just as present. In addition to binding regimes to democracy and the protection of rights, the Larreta Doctrine sought to tie small, medium, and great powers alike to processes of collective decision making, without conferring special veto rights on the largest states. Naturally, Uruguay could not wholly prevent the United States from unilateral actions, but by privileging multilateral mechanisms in yet another field of action, it would further delegitimize any intervention that took place outside that context. Small and large would be bound by the decisions of the collective, at least legally and institutionally, if not always in effect.
The Larreta Doctrine may be a footnote of history, but its core proposals are of immediate relevance. As initially proposed, its life was short. However, it emerged from and advanced critical discussions on the relationship between domestic democracy and human rights and the regional international community. It helped make space for democratic and human rights clauses that gained greater force over the ensuing decades through interAmerican human rights regimes and growing collective commitments to democracy (Legler and Tieku 2010; Meza Salazar 2002). It was, without a doubt, ahead of its time. The conditions that inspired Rodríguez Larreta's proposal also complicated its path: democratic governance was too feeble and sparse, and the record of great power restraint too short. However, the episode provides a useful and largely unexplored attempt by a small state to persuade its neighbors to adopt a regional precommitment to the collective protection of human rights and democracy, with the crucial caveat that it must be not only the weak state that commits but also powerful neighbors and indeed the whole region. As with R2P, it is ultimately impossible to separate the doctrine from considerations of power, both in terms of Uruguayan concerns about Argentina and the context of hemispheric asymmetry. Rodríguez Larreta and the ensuing debate elucidate possible responses to the dilemmas of (non)intervention, which some vulnerable states were ready to adopt. This is not because they were less jealous of their sovereignty or embraced interventionism, but because they conceptualized both quite differently. A collective regional decision to protect the democratic or human rights of a nation whose representatives had freely agreed to such a regime did not violate sovereignty, but ensured it.

\section{Notes}

1 Following Spanish-language custom, his last name combines the patronymic Rodríguez and the matronymic Larreta, but his proposal came to be known as the Larreta Doctrine.

2 We thank Shirin Rai for suggesting this phrase.

3 Cf. Moyn (2010), who argues this regime emerged in the 1970s, and Kelly (2018) who makes this argument regarding Latin America.

4 Cuban Foreign Ministry, Puntos de vista del gobierno de Cuba sobre la organización internacional para la paz, August 14, 1944, Folder III-635-1(6a). Archives of the Mexican Foreign Ministry (hereafter, SREMEX), Mexico City.

5 Discussed in William Dawson [US Ambassador in Uruguay] to Secretary of State James Byrnes, October 31, 1945, FRUS (1945), vol. IX, doc. 128.

6 Rodríguez Larreta, November 21, 1945. Nota del gobierno del Uruguay. In Pan-American Union, Consulta del gobierno del Uruguay y contestaciones de los gobiernos sobre paralelismo entre la democracia y la paz 
(hereafter Consulta) May 1946, in Folder III-1156-2 (27bis), SRE-MEX. English translation in FRUS, 1945, vol. IX, doc. 131.

7 Dawson to Byrnes, No. 6568, November 7, 1945 , 835.00/11-745, RG 59, US National Archives, College Park, MD (hereafter NARA).

8 Rodríguez Larreta, Nota del gobierno del Uruguay dirigida a los otros gobiernos de las otras repúblicas americanas, February 2, 1946, Consulta, SRE-MEX.

9 Clip located in Oficios 1945, Montevidéu, 34/2/1, Archive of the Brazilian Foreign Ministry [hereafter AHIR]. Rio de Janeiro.

10 Cited in Teixeira Soares, Mes político no. 11, December 18, 1945, Oficios 1945, Montevidéu, 34/2/2, AHIR.

11 Rodríguez Larreta let the State Department see an early draft of his proposal. See FRUS 1945, vol. IX, doc. 130 .

12 Clip located in Oficios 1945, Montevidéu, 34/2/2, AHIR.

13 Byrnes to Dawson, No. 404, October 24, 1945, 835.00/10-2445, RG 59, NARA; Byrnes to Dawson, No. 445, November 20, 1945, 835.00/11-2045, RG 59, NARA.

14 Dawson to Byrnes, No. 691, October 31, 1945 , 835.00/10-3145, RG 59, NARA; Dawson to Byrnes, November 7, 1945, 835.00/11-745, RG 59, NARA.

15 Byrnes, circular telegram, November 24, 1945, 835.00/11-2445, RG 59, NARA.

16 Byrnes, press release, November 27, 1945, 710.11/112745, RG 59, NARA.

17 Briggs to Austin, December 7, 1945, 710.11/12-745, RG 59, NARA.

18 Guillermo Toriello, Contestación del gobierno de Guatemala, November 30, 1945, Consulta, SRE-MEX.

19 Fernando Lodoño, Contestación del gobierno de Colombia, December 24, 1945, Consulta, SRE-MEX; see also FRUS, 1945, vol. IX, doc. 156.

20 Chilean Embassy in Colombia, Folder 2293, Fondo Histórico, Archivo Ministerio de Relaciones Exteriores, Santiago, Chile.

21 Fernando Castillo Nájera, Contestación del gobierno de México, December 10, 1945, Consulta.

22 Nicaragua added that those out of power might use the principle "to question each act of the government, which would be prejudicial to internal order and international harmony." Mariano Agüero, "Contestación del gobierno de Nicaragua," January 1, 1946, Consulta, SRE-MEX.

23 Héctor Escobar Serrano, Contestación del gobierno de El Salvador, December 13, 1945, Consulta, SRE-MEX.

24 Ibid., p. 7.

25 Draft letter to Rodríguez Larreta, Contestación del gobierno de México, March 19, 1946, in folder III1156-2 (27bis), SRE-MEX.
26 Brazilian Embassy in Mexico to the Minister, Reação mexicana ao projeto uruguaio de intervenção em outros países, December 11, 1945, Mexico Oficios, 32/3/6, AHIR.

27 Clip located in Oficios 1946, Montevidéu, 34/2/6, AHIR.

28 Cabot [Buenos Aires] to William P. Cochran [Chief, Division of Caribbean and Central American Affairs], December 14, 1945, Diplomatic Papers of John Moors Cabot, Part 1 (Reel 1), University Publications of America, Harry S. Truman Presidential Library, Independence, MO.

29 Acta de la sesión extraordinaria del consejo directivo de la Unión Panamericana, July 17, 1946, Folder III2313-1(7a), SRE-MEX.

\section{References}

Álvarez, Alejandro. 1944. "Bases y Principios del Derecho Internacional Moderno." Anales de la Facultad de Ciencias Jurídicos y Sociales 10: 37-40.

Antokoletz, Daniel. 1944. Tratado de Derecho Internacional Público en Tiempo de Paz y en Tiempo de Guerra, 4th edition. Buenos Aires: Librería y editorial La Facultad, Bernabe y cía.

Ayoob, Mohammed. 2002. "Humanitarian Intervention and State Sovereignty." International Journal of Human Rights 6(1): 81-102.

Bellamy, Alex J. 2008. "The Responsibility to Protect and the Problem of Military Intervention." International Affairs 84(4): 615-39.

Buchanan, Allen and Robert O. Keohane. 2011. "Precommitment Regimes for Intervention: Supplementing the Security Council." Ethics \& International Affairs 25(1): 41-63.

Cabranes, José A. 1967. "Human Rights and NonIntervention in the Inter-American System." Michigan Law Review 65(6): 1147-82.

Calvo, Carlos. 1877. Le Droit International Théorique et Pratique, Vol. I, 4th edition. Paris: Guillaumin et Cie. Casal Tatlock, Álvaro, ed. 1997. La Doctrina Larreta. Montevideo: Ediciones de la Plaza.

Closa, Carlos and Stefano Palestini. 2018. "Tutelage and Regime Survival in Regional Organizations' Democracy Protection: The Case of MERCOSUR and UNASUR." World Politics 70(3): 443-76.

Cooper, Andrew F. and Thomas Legler. 2001. "The OAS Democratic Solidarity Paradigm: Questions of Collective and National Leadership." Latin American Politics and Society 43(1): 103-26. 2006. Intervention without Intervening?: The OAS Defense and Promotion of Democracy in the Americas. New York: Springer.

Daalder, Ivo and James Lindsay. 2007. "Democracies of the World, Unite." The American Interest 2(3): $47-58$. 
Department of State Central Files (Records Group 59). United States National Archives and Records Administration. College Park, MD: US NARA.

Donno, Daniela. 2010. "Who Is Punished? Regional Intergovernmental Organizations and the Enforcement of Democratic Norms." International Organization 64(4): 593-625.

Drago, Luis María. 1903. La República Argentina y el caso de Venezuela. Buenos Aires: Coni Hermanos.

El Debate [Montevideo]. 1945. "Un atentado al sentido común: La ridícula nota cancilleresca pro intervención," November 26.

El Pais [Montevideo]. 1946a. "Una frase de Ruy Barbosa," January 7.

El Pais [Montevideo]. 1946b. "El Uruguay, con su Doctrina, Culmina Nueva Etapa del Derecho Internacional," October 23.

Engstrom, Par. 2016. "The Inter-American Human Rights System and U.S.-Latin American Relations." In Cooperation and Hegemony in US-Latin American Relations: Revisiting the Western Hemisphere Idea, eds. Juan Pablo Scarfi and Andrew Tillman, 209-47. Basingstoke: Palgrave Macmillan.

Evans, Gareth J. 2008. The Responsibility to Protect: Ending Mass Atrocity Crimes Once and for All. Washington, DC: Brookings Institution.

Fabela, Isidro. 1991. Intervención, 2nd edition. Mexico City: Universidad Nacional Autónoma de México.

Feldmann, Andreas, Federico Merke, and Oliver Stuenkel. 2019. "Argentina, Brazil and Chile and Democracy Defence in Latin America: Principled Calculation." International Affairs 95(2): 447-67.

Fenwick, Charles G. 1964. "The Recognition of de facto Governments: Is There a Basis for Inter-American Collective Action?" American Journal of International Law 58(1): 109-13.

Foreign Relations of the United States [FRUS]. 1945. Diplomatic Papers, 1945: The American Republics, Vol. IX. Washington, DC: US Government Printing Office.

Franck, Thomas M. 1992. "The Emerging Right to Democratic Governance." American Journal of International Law 86(1): 46-91.

Friedman, Max Paul and Tom Long. 2015. "Soft Balancing in the Americas: Latin American Opposition to U.S. Intervention, 1898-1936." International Security 40(1): 120-56.

Glanville, Luke. 2014. Sovereignty and the Responsibility to Protect: A New History. Chicago: University of Chicago Press.

_ 2017. "Responsibility to Perfect: Vattel's Conception of Duties beyond Borders." International Studies Quarterly 61(2): 385-95.

Goldman, Robert K. 2009. "History and Action: The Inter-American Human Rights System and the Role of the Inter-American Commission on Human Rights." Human Rights Quarterly 31: 856-87.

Hafner-Burton, Emilie M. and Kiyoteru Tsutsui. 2005. "Human Rights in a Globalizing World: The Paradox of Empty Promises." American Journal of Sociology 110(5): 1373-1411.

Hathaway, Oona and Shapiro Scott. 2017. The Internationalists: How a Radical Plan to Outlaw War Remade the World. New York: Simon \& Schuster.

Hawkins, Darren and Carolyn Shaw. 2007. "The OAS and Legalizing Norms of Democracy." In Promoting Democracy in the Americas, eds. Thomas Legler, Sharon F. Lean, and Dexter S. Boniface, 21-39. Baltimore: Johns Hopkins University Press.

Hehir, Aidan. 2011. "A Response to 'Precommitment Regimes for Intervention.” Ethics \& International Affairs Online. https://www.ethicsandinternationalaffairs.org/ 2011/a-response-to-precommitment-regimes-forintervention.

Heine, Jorge and Brigitte Weiffen. 2015. 21st Century Democracy Promotion in the Americas: Standing up for the Polity. New York: Routledge.

Ikenberry, G. John and Anne-Marie Slaughter. 2006. Forging a World of Liberty under Law: U.S. National Security in the 21st Century. Princeton, NJ:

Woodrow Wilson School of Public and International Affairs.

Inter-American Treaty of Reciprocal Assistance. 1947. Signed at Inter-American Conference for the Maintenance of Continental Peace and Security. September 2, 1947. 21 U.N.T.S., 324.

Jahn, Beate. 2005. "Barbarian Thoughts: Imperialism in the Philosophy of John Stuart Mill." Review of International Studies 31(3): 599-618.

Kelly, Patrick William. 2018. Sovereign Emergencies: Latin America and the Making of Global Human Rights Politics. New York: Cambridge University Press.

Kesler, John C. 1985. "Spruille Braden as a Good Neighbor: The Latin American Policy of the United States." PhD dissertation, Kent State University.

Krasner, Stephen D. 1999. Sovereignty: Organized Hypocrisy. Princeton, NJ: Princeton University Press.

Langley, Lester D. 2010. America and the Americas: The United States in the Western Hemisphere. Athens: University of Georgia Press.

Legler, Thomas and Thomas Kwasi Tieku. 2010. "What Difference Can a Path Make? Regional Democracy Promotion Regimes in the Americas and Africa." Democratization 17(3): 465-91.

Lorca, Arnulf Becker. 2014. Mestizo International Law: A Global Intellectual History 1842-1933. Cambridge: Cambridge University Press.

Lutz, Ellen L. and Kathryn Sikkink. 2000. "International Human Rights Law and Practice in Latin America." International Organization 54(3): 633-59. 
Makinda, Samuel M. and F. Wafula Okumu. 2007. The African Union: Challenges of Globalization, Security, and Governance. New York: Routledge.

Mansfield, Edward D. and Jon C. Pevehouse. 2006. "Democratization and International Organizations." International Organization 60(1): 137-67.

Marques Castro, Mateo. 1947. Conferencia Interamericana para el Mantenimiento de la Paz y la Seguridad del Continente. Montevideo: Ministerio de Relaciones Exteriores.

Mboya, Tom. 2009. "Conflict between State Sovereignty and the Right of Intervention under the Constitutive Act of the African Union." Africa Insight 39(2): 77-89.

Meza Salazar, Sergio. 2002. "La Democracia y el Sistema Interamericano: De la Carta de la OEA a la Carta Democrática." Agenda Internacional 8(16): 97-122.

Mill, John Stuart. 1867. "A Few Words on Nonintervention." In Dissertations and Discussions: Political, Philosophical, and Historical, 171-76. Boston: Spencer.

Moravcsik, Andrew. 2000. "The Origins of Human Rights Regimes: Democratic Delegation in Postwar Europe." International Organization 54(2): 217-52.

Moyn, Samuel. 2010. The Last Utopia: Human Rights in History. Cambridge, MA: Belknap Press.

Organization of American States (OAS). 1948. Charter of the Organization of American States. Bogotá, Colombia, April 30.

. (OAS). 1959. "Final Act, Fifth Meeting of Consultation of Ministers of Foreign Affairs," Santiago, Chile. August 12-18. http://www.oas.org/council/ MEETINGS\%20OF\%20CONSULTATION/Actas/ Acta\%205.pdf.

. (OAS). 1960. Special Report on the Relationship

Between Violations of Human Rights or the Nonexercise of Representative Democracy and the Political Tensions that Affect the Peace of the Hemisphere. Washington, DC: Pan American Union.

(OAS). 2001. Inter-American Democratic Charter. Washington, DC: Organization of American States.

Paniagua, G. 1945.“La Neo-Intervención. El Canciller uruguayo propone una peligrosa doctrina de política internacional." Asi, December 22.

Peters, Anne. 2009. "Humanity as the $A$ and $\Omega$ of Sovereignty." European Journal of International Law 20(3): 513-44.
Pevehouse, Jon C. 2002. "Democracy from the OutsideIn? International Organizations and Democratization." International Organization 56(3): 515-49.

Poast, Paul and Johannes Urpelainen. 2015. "How International Organizations Support Democratization: Preventing Authoritarian Reversals or Promoting Consolidation?" World Politics 67(1): 72-113.

Sabato, Hilda. 2018. Republics of the New World: The Revolutionary Political Experiment in NineteenthCentury Latin America. Princeton, NJ: Princeton University Press.

Scarfi, Juan Pablo. 2017. The Hidden History of International Law in the Americas: Empire and Legal Networks. New York: Oxford University Press.

Schwartzberg, Steven. 2003. Democracy and U.S. Policy in Latin America during the Truman Years. Gainesville: University Press of Florida.

Serbin, Andrés and Andrei Serbin Pont. 2015. "Latin America and the Responsibility to Protect: Divergent Views from the South?” Pensamiento Propio 41: 11-34.

Serbin, Andrés and Gilberto M. A. Rodrigues. 2011. "The Relevance of the Responsibility to Protect for Latin America and the Caribbean Region: Prevention and the Role of Civil Society." Global Responsibility to Protect 3(3): 266-85.

Sikkink, Kathryn. 1996. "Reconceptualizing Sovereignty in the Americas: Historical Precursors and Current Practices." Houston Journal of International Law 19(3): 705-24.

- 2014. "Latin American Countries as Norm Protagonists of the Idea of International Human Rights." Global Governance 20(3): 389-404. . 2018. Evidence for Hope: Making Human Rights Work in the 21st Century. Princeton, NJ: Princeton University Press.

Simmons, Beth A. 2009. Mobilizing for Human Rights: International Law in Domestic Politics. New York: Cambridge University Press.

Simmons, Beth Ann and Allison Danner. 2010. "Credible Commitments and the International Criminal Court." International Organization 64(2): 225-56.

Whyte, Jessica. 2016 "Always on Top'? The 'Responsibility to Protect' and the Persistence of Colonialism." In The Postcolonial World, eds. Jyotsna G. Singh and David D. Kim, 308-24. London: Routledge. 